\title{
The antiproteinuric effect of ATP-sensitive potassium channel activator flocalin on the models of experimental nephropathies
}

\author{
N.D. Filipets ${ }^{1}$, A.I. Gozhenko², O.O. Filipets' ${ }^{1}$, O.A. Gozhenko², V.M. Sirman² \\ ${ }^{1}$ Higher State Educational Establishment «Bukovinian State Medical University», Chernivtsi; \\ ${ }^{2}$ State enterprise «Ukrainian Research Institute for Medicine of Transport of Ministry of Health of \\ Ukraine»,Odessa; e-mail: filipec.natalja@bsmu.edu.ua
}

\begin{abstract}
In experiments on laboratory non-linear white rats with sublimate nephropathy (mercury dichloride, 5 mg/ $\mathrm{kg}$ subcutaneously) and hypoxic histohemic nephropathy (HHHN; sodium nitrite, $50 \mathrm{mg} / \mathrm{kg}$ subcutaneously and 2,4-dinitrophenol, $3 \mathrm{mg} / \mathrm{kg}$ intraperitoneally) the effect of ATP-sensitive potassium ( $K_{\text {ATP }}$ ) channels activation induced by flocalin (5 $\mathrm{mg} / \mathrm{kg}$ intragastric administration, for 7 days) on kidney protein excretion was studied. Flocalin use causes a decrease in standardized by glomerular filtration rate proteinuria: by 4.5 times and 1.2 times in rats with both acute and chronic sublimate nephropathy; and by 1.6 and 2.1 times, simultaneously, under the conditions of hypoxic injury of nephrocytes. Antiproteinuric effect of flocalin during both acute and chronic periods of nephropathy was accompanied by an increase in enzymatic activity of alkaline phosphatase (by $18.1 \%$ and $49.9 \%$ - in rats with sublimate nephropathy; by $18.1 \%$ and $4 \%$ - in rats with HHHN) and succinate dehydrogenase (by $36.3 \%$ and $56.7 \%$ in rats with sublimate nephropathy; reaches control level in rats with acute HHHN and increases by $71.2 \%$ in rats with chronic $H H H N)$ in kidney cortex. Conclusion was made about the nephroprotective effect of $K_{A T P}$-channels activation induced by flocalin predominantly in the proximal part of nephrons.

Key words: $K_{A T P}$-channels activator flocalin; experimental nephropathy.
\end{abstract}

\section{INTRODUCTION}

$\mathrm{K}_{\mathrm{ATP}}$-channels are important regulators of excitant tissues functioning and their role in myocardium protection in hypoxia and ischemia is well known. The cardioprotective mechanism based on $\mathrm{K}_{\text {ATP }}$-channels mediated interconnection between energy state and electrophysiological activity of cardiomyocytes [1] has been proven by numerous studies with the use of pharmacological modulators of the potassium flow [2-4]. Understanding of biological role of this type of channels and clinical perspectives of the relevant research of pharmacotherapy is based on scientifically grounded findings regarding protective influence of fluorine containing $\mathrm{K}_{\mathrm{ATP}}$-channels activators on physiological and biochemical processes. It has been stated that among new modulators of potassium flow the most perspective medicine with cardioprotective and vasolytic effects is flocalin which is an activator of $\mathrm{K}_{\mathrm{ATP}}$-channels of sarcolemmal and mitochondrial membrane $[5,6]$.

Versatility of the protective mechanisms of flocalin, metabolic support of cardiac activity and of required central hemodynamics anticipates the possible nephrotropic effect of the compound. Generally recognized cardiorenal continuum reflects the existence of relatively persistent metabolic interconnections in the organism in physiological conditions and pathology [7]. Development and progression of the combined cardiac and renal disorders are mediated by the chains of complicated neural and hormonal mechanisms of feedback (functional activity of vasoconstrictive, antinatriuretic systems and their antagonists). The elabora- 
tion of pathogenesis allowed for considering cardioprotection and nephroprotection the basic directions for prevention of cardiorenal syndrome. Thus, nephroprotective effect of cardiovascular drugs allows for maintaining kidney functions in the diseases when the kidneys are targeted.

Potassium channels in kidneys have various functions starting from ion balance support and volume regulation to the regulation of renin synthesis and finally angiotensin II generation [8]. The results of renal $\mathrm{K}_{\mathrm{ATP}}$-channels activators studies are ambiguous that gives evidence of the complexity of this research. The reason may be that modern representatives of potassium flow activators are not selective regarding renal $\mathrm{K}_{\text {ATP }}{ }^{-}$ channels and have adverse effects [9]. Unlike the reference drugs (the other potassium flow activators) the new $\mathrm{K}_{\mathrm{ATP}}$-channels activators including flocalin contain the fluorine atom in their molecule that determines higher selectivity and significantly lower toxicity [10].

An important marker of the protective effect of the pharmacological correctors on the structural and functional state of kidneys, as well as direct marker of chronic kidney disease (CKD) progression, is dynamics of proteinuria. The increase of protein excretion in the urine occurs in any kind of renal pathology as a result of debilitation of the reserve capabilities of the proximal tubules where protein is not absorbed after glomerular filtration [11]. Proteinuria is also an effector of nephropathy. This fact can be confirmed by the protein induced apoptosis of epithelial and endothelial cells of the nephron [12]. Violation of the apoptosis when cell death prevails over cell proliferation to a large extent induces glomerular and interstitial sclerosis which is the basis for CKD progression. Thus, proteinuria level is informative for the assessment of prognosis of the outcome and treatment efficacy in renal pathology.

In our research we aimed to study the influence of $\mathrm{K}_{\mathrm{ATP}}$-channels activator flocalin on proteinuria dynamics in the rats with different models of experimental nephropathy.

\section{METHODS}

The experiments were made on 84 laboratory non-linear white rats $0.15-0.17 \mathrm{~kg}$ of weight with sublimate and hypoxic kidney injury. All the operations with experimental animals were performed according to the national requirements of "The General Ethic Principles of Experiments on Animals" (Kyiv, 2011) conformed to the regulations of "The European Convention for the Protection of Vertebrate Animals used for Experimental and other Scientific Purposes" (Strasbourg, 1985).

The model of sublimate nephropathy was made by a single subcutaneous injection of $0.1 \%$ solution of mercuric dichloride in the dose $5 \mathrm{mg} / \mathrm{kg}$. Hypoxic histohemic nephropathy (HHHN) was modeled with the patented method of sequential administration of sodium nitrite and 2,4-dinitrophenol [13]. The rats with experimental nephropathies were divided into two series for the analysis of acute $\left(1^{\text {st }}\right.$ series $)$ and chronic $\left(2^{\text {nd }}\right.$ series) kidney damage induced by sublimate and of hypoxic origin. In each series the rats from Group I were left without correction and the rats from Group II received intraventricular probe administration of flocalin in the dose $5 \mathrm{mg} / \mathrm{kg}$ on $1 \%$ starch mucus $5 \mathrm{ml} / \mathrm{kg}$ during 7 days. To the rats with acute nephropathy we administered flocalin from the first day of pathology modeling, whereas the rats with chronic nephropathy received flocalin from the $30^{\text {th }}$ day after nephrotoxins administration. The control group of rats received starch mucus in the same amount.

After the last dose of flocalin all the rats went through water load in the amount of $5 \%$ of body weight and were placed into exchange cages for two hours for urine collection. Euthanasia of rats was done under light ether anesthesia. The indexes of kidney function were calculated for $100 \mathrm{~g}$ of weight and $100 \mu \mathrm{l}$ of glomerular filtrate (GF). For glomerular filtration rate (GFR) assessment we measured creatinine level in the urine on photoelectric colorimeter by the method of Folin. Plasma creatinine was assessed by the method of Popper in A.K. Merson modification 
by reaction with picric acid with subsequent colorimetry on the spectrophotometer SP46. Protein concentration in the urine was determined by sulfosalicylic method. For the possible interrelation between the dynamics of proteinuria and biochemical state of the nephrocytes at all stages of experiment after the course administration of flocalin we studied particular indexes of energy metabolism alkaline phosphatase (AP) [EC 3.1.3.1] in renal cortex and succinate dehydrogenase (SDH) [EC 1.3.5.1] in renal cortex and medulla [14].

The indexes that characterized the functional state of kidneys were calculated by the generally accepted formulae. Statistical processing was performed with «Statgrafics». The significance of differences of the results was assessed with parametric Student's t-test.

\section{RESULTS AND DISCUSSION}

In experimental sublimate nephropathy a large number of mercury ions appear in the tubular part of nephron with filtrated plasma due to intensive blood supply of kidneys. Violation of the structural and biochemical state of tubulocytes is a result of the contact of mercury ions with sulfhydryl groups of proteins of apical membrane. Heavy injury of renal epithelium, particularly of proximal tubules leads to the decrease of reabsorption of water, electrolytes and protein. An important role in the functional adaptation of the damaged kidney is played by tubular-tubular balance: inhibition of reabsorption in the proximal part of nephron is followed by simultaneous increase of distal transport. This mechanism of internal nephron compensation maintains the stability of salt and liquid in the organism but it doesn't concern the reabsorption of protein, as organic substances are not reabsorbed in the distal tubules.

In our study the sublimate nephropathy in acute phase manifested by 2.2 times increase of protein concentration in the urine and more than twentyfold increase of protein excretion calculated by GF (Table 1).
A significant difference of indexes in experimental and control (intact rats) groups gives evidence of heavy injury of the tubulocytes which is inherent to heavy metals effect and leads to pathology progression. In the rats with chronic kidney injury protein excretion increased by $80 \%$ in two hours. The differences of the other indexes were less pronounced, unlike the results in acute nephropathy. Protein concentration in the urine and protein excretion standardized by the filtrated in renal glomeruli liquid increased 1.5 times in comparison with the control. However the increase of protein excretion pointed at proteinuria predominantly of tubular origin.

Influenced by flocalin induced $\mathrm{K}_{\mathrm{ATP}}$-channels activation protein concentration in the urine decreased fivefold and two-hour and standardized by GF proteinuria decreased significantly (by 4.5 times). After a course administration of flocalin starting from the $30^{\text {th }}$ day of renal pathology high protein content in the urine was retained: the difference with the control was $126.3 \%$ and with the untreated group $53.6 \%$. The development of pathological process in kidneys is combined with the mechanism of compensatory decrease of GFR to the amount of ultrafiltrate that can be reabsorbed in renal tubules. In conditions of the increased blood supply to the kidneys due to vasodilatation effect of $\mathrm{K}_{\text {ATP }}$-channels opener much more protein permeated to primary urine through glomeruli that were damaged by the sublimate. However the excretion measurement in two hours didn't show any reduction of protein loss with the urine. At the same time in the rats with sublimate induced chronic nephrocytes damage the activation of $\mathrm{K}_{\mathrm{ATP}}$-channels led to the decrease of proteinuria standardized by GF (by 1.2 times) that pointed at the intensification of renal transport processes on cellular and tubular levels.

Hypoxia can be a trigger or an accompanying factor of renal pathology in case of the damage caused by any of the nephrotoxic agents. The decrease of oxygen pressure despite intensive blood supply of kidneys (which is $20 \%$ of cardiac output) manifests as violation of the 
basic homeostasis processes primarily in the tubular part of nephron. At the initial stage of acute HHHN protein concentration in the urine increased ninefold and protein excretion in two hours increased 5.6 times. Our model of HHHN is characterized by the combination of the reduced transport function of blood due to sodium nitrite effect with disorder in the system of oxy-

Table 1. The influence of flocalin induced $K_{A T P}$-channels activation $(5 \mathrm{mg} / \mathrm{kg}, 7$ days) on the dynamics of proteinuria in rats with acute and chronic kidney injury $(x \pm S x, n=7)$

\begin{tabular}{|c|c|c|c|}
\hline Index & $\begin{array}{l}\text { Intact rats } \\
\text { (Control) }\end{array}$ & $\begin{array}{l}\text { Nephropathy } \\
\text { (Group I) }\end{array}$ & $\begin{array}{c}\text { Nephropathy and flocalin } \\
\text { (Group II) }\end{array}$ \\
\hline \multicolumn{4}{|c|}{ Acute sublimate nephropathy } \\
\hline \multirow[t]{2}{*}{ Diuresis, $\mathrm{ml} / 2 \mathrm{~h} \cdot 100 \mathrm{~g}$} & $4.7 \pm 0.11$ & $2.9 \pm 0.25$ & $3.0 \pm 0.46$ \\
\hline & & $\mathrm{P}<0.01$ & $\mathrm{P}<0.01$ \\
\hline \multirow[t]{2}{*}{ Protein concentration in urine, $\mathrm{g} / \mathrm{l}$} & $0.018 \pm 0.0013$ & $0.04 \pm 0.006$ & $0.008 \pm 0.0009$ \\
\hline & & $\mathrm{P}<0.01$ & $\mathrm{P}<0.01 ; \mathrm{P}_{1}<0.01$ \\
\hline \multirow[t]{2}{*}{ Protein excretion, $\mathrm{mg} / 2 \mathrm{~h} \cdot 100 \mathrm{~g}$} & $0.09 \pm 0.005$ & $0.13 \pm 0.027$ & $0.02 \pm 0.004$ \\
\hline & & & $\mathrm{P}<0.001 ; \mathrm{P}_{1}<0.01$ \\
\hline \multirow[t]{3}{*}{ Protein excretion, $\mathrm{mg} / 100 \mu \mathrm{lGF}$} & $0.018 \pm 0.0022$ & $0.041 \pm 0.0930$ & $0.009 \pm 0.0012$ \\
\hline & & $\mathrm{P}<0.01$ & $\mathrm{P}<0.01 ; \mathrm{P}_{1}<0.01$ \\
\hline & ic sublimate $n$ & ropathy & \\
\hline \multirow[t]{2}{*}{ Diuresis, $\mathrm{ml} / 2 \mathrm{~h} \cdot 100 \mathrm{~g}$} & $3.4 \pm 0.26$ & $4.1 \pm 0.07$ & $2.3 \pm 0.27$ \\
\hline & & $\mathrm{P}<0.05$ & $\mathrm{P}<0.05 ; \mathrm{P}_{1}<0.01$ \\
\hline \multirow[t]{2}{*}{ Protein concentration in urine, $\mathrm{g} / \mathrm{l}$} & $0.019 \pm 0.0018$ & $0.028 \pm 0.0017$ & $0.043 \pm 0.0022$ \\
\hline & & $\mathrm{P}<0.01$ & $\mathrm{P}<0.001 ; \mathrm{P}_{1}<0.01$ \\
\hline \multirow{2}{*}{ Protein excretion, $\mathrm{mg} / 2 \mathrm{~h} \cdot 100 \mathrm{~g}$} & $0.064 \pm 0.0062$ & $0.115 \pm 0.0084$ & $0.099 \pm 0.0135$ \\
\hline & & $\mathrm{P}<0.01$ & $\mathrm{P}<0.05$ \\
\hline \multirow[t]{2}{*}{ Protein excretion, $\mathrm{mg} / 100 \mu \mathrm{l} \mathrm{GF}$} & $0.025 \pm 0.0017$ & $0.037 \pm 0.0022$ & $0.030 \pm 0.0017$ \\
\hline & & $\mathrm{P}<0.01$ & $\mathrm{P}_{1}<0.05$ \\
\hline \multicolumn{4}{|c|}{ Acute hypoxic histohemic nephropathy } \\
\hline \multirow[t]{2}{*}{ Diuresis, $\mathrm{ml} / 2 \mathrm{~h} \cdot 100 \mathrm{~g}$} & $3.0 \pm 0.15$ & $3.7 \pm 0.16$ & $3.6 \pm 0.21$ \\
\hline & & $\mathrm{P}<0.05$ & $\mathrm{P}<0.05$ \\
\hline \multirow[t]{2}{*}{ Protein concentration in urine, $g / 1$} & $0.004 \pm 0.0006$ & $0.038 \pm 0.0038$ & $0.021 \pm 0.0040$ \\
\hline & & $\mathrm{P}<0.001$ & $\mathrm{P}<0.01 ; \mathrm{P}_{1}<0.01$ \\
\hline \multirow[t]{2}{*}{ Protein excretion, $\mathrm{mg} / 2 \mathrm{~h} \cdot 100 \mathrm{~g}$} & $0.013 \pm 0.0005$ & $0.073 \pm 0.0170$ & $0.037 \pm 0.0041$ \\
\hline & & $\mathrm{P}<0.05$ & $\mathrm{P}<0.01$ \\
\hline \multirow[t]{2}{*}{ Protein excretion, $\mathrm{mg} / 100 \mu \mathrm{lGF}$} & $0.003 \pm 0.0005$ & $0.016 \pm 0.0012$ & $0.010 \pm 0.0014$ \\
\hline & & $\mathrm{P}<0.001$ & $\mathrm{P}<0.01 ; \mathrm{P}_{1}<0.05$ \\
\hline \multicolumn{4}{|c|}{ Chronic hypoxic histohemic nephropathy } \\
\hline \multirow[t]{2}{*}{ Diuresis, $\mathrm{ml} / 2 \mathrm{~h} \cdot 100 \mathrm{~g}$} & $4.8 \pm 0.12$ & $4.3 \pm 0.18$ & $4.4 \pm 0.08$ \\
\hline & & $\mathrm{P}<0.05$ & $\mathrm{P}<0.05$ \\
\hline \multirow[t]{2}{*}{ Protein concentration in urine, $g / 1$} & $0.018 \pm 0.0013$ & $0.026 \pm 0.0009$ & $0.023 \pm 0.0013$ \\
\hline & & $\mathrm{P}<0.001$ & $\mathrm{P}<0.05$ \\
\hline \multirow[t]{2}{*}{ Protein excretion, $\mathrm{mg} / 2 \mathrm{~h} \cdot 100 \mathrm{~g}$} & $0.088 \pm 0.0054$ & $0.112 \pm 0.0022$ & $0.102 \pm 0.0047$ \\
\hline & & $\mathrm{P}<0.01$ & \\
\hline \multirow[t]{2}{*}{ Protein excretion, $\mathrm{mg} / 100 \mu \mathrm{lGF}$} & $0.018 \pm 0.0023$ & $0.035 \pm 0.0026$ & $0.017 \pm 0.0014$ \\
\hline & & $\mathrm{P}<0.01$ & $\mathrm{P}_{1}<0.01$ \\
\hline
\end{tabular}

Notes: $\mathrm{P}$ - significance of differences compared to control; $\mathrm{P}_{1}-$ significance of differences compared to untreated rats; GF - glomerular filtration. 
The antiproteinuric effect of atp-sensitive potassium channel activator flocalin on the models of experimental nephropathies

Table 2. The influence of flocalin induced $\mathrm{K}_{\mathrm{ATP}}$-channels activation $(5 \mathrm{mg} / \mathrm{kg}, 7$ days) on the activity of alkaline phosphatase and succinate dehydrogenase in renal tissues of the rats with acute and chronic kidney injury $(x \pm S x, n=7)$

\begin{tabular}{|c|c|c|c|c|c|}
\hline \multirow[t]{2}{*}{ Index } & \multirow{2}{*}{$\begin{array}{l}\text { Intact rats } \\
\text { (Control) }\end{array}$} & \multicolumn{2}{|c|}{$\begin{array}{l}\text { Nephropathy } \\
\text { (Group I) }\end{array}$} & \multicolumn{2}{|c|}{$\begin{array}{l}\text { Nephropathy and flocalin } \\
\text { (Group II) }\end{array}$} \\
\hline & & AKI & CKI & AKI & CKI \\
\hline \multicolumn{6}{|c|}{ Sublimate nephropathy } \\
\hline \multicolumn{6}{|c|}{ Renal cortex } \\
\hline AAP, units & $119.9 \pm 1.60$ & $50.9 \pm 1.16$ & $76.1 \pm 3.02$ & $55.1 \pm 1.06$ & $113.7 \pm 6.14$ \\
\hline \multirow{3}{*}{ ASDH, units } & & $\mathrm{P}<0.001$ & $\mathrm{P}<0.001$ & $\mathrm{P}<0.001 ; \mathrm{P}_{1}<0.05$ & $\mathrm{P}_{1}<0.01$ \\
\hline & $41.3 \pm 4.40$ & $28.6 \pm 1.32$ & $24.3 \pm 3.90$ & $39.0 \pm 4.49$ & $38.1 \pm 4.22$ \\
\hline & & $\mathrm{P}<0.05$ & $\mathrm{P}<0.05$ & $\mathrm{P}_{1}<0.05$ & $\mathrm{P}_{1}<0.05$ \\
\hline \multicolumn{6}{|c|}{ Renal medulla } \\
\hline ASDH, units & $30.5 \pm 1.54$ & $16.8 \pm 1.83$ & $19.5 \pm 2.01$ & $20.1 \pm 2.20$ & $27.3 \pm 4.54$ \\
\hline & & $\mathrm{P}<0.01$ & $\mathrm{P}<0.01$ & $\mathrm{P}<0.01$ & \\
\hline \multicolumn{6}{|c|}{ Hypoxic histohemic nephropathy } \\
\hline AAP, units & $119.9 \pm 1.60$ & $95.5 \pm 3.79$ & $113.5 \pm 1.01$ & $112.8 \pm 3.62$ & $118.1 \pm 1.59$ \\
\hline \multirow{3}{*}{ ASDH, units } & & $\mathrm{P}<0.01$ & $\mathrm{P}<0.05$ & $\mathrm{P}_{1}<0.05$ & $\mathrm{P}_{1}<0.05$ \\
\hline & $41.3 \pm 4.40$ & $24.8 \pm 1.58$ & $10.1 \pm 1.32$ & $29.4 \pm 4.13$ & $17.3 \pm 0.46$ \\
\hline & & $\mathrm{P}<0.05$ & $\mathrm{P}<0.01$ & & $\mathrm{P}<0.01 ; \mathrm{P}_{1}<0.01$ \\
\hline \multicolumn{6}{|c|}{ Renal medulla } \\
\hline ASDH, units & $30.5 \pm 1.54$ & $15.9 \pm 1.86$ & $16.6 \pm 0.75$ & $16.4 \pm 1.43$ & $20.7 \pm 3.87$ \\
\hline & & $\mathrm{P}<0.01$ & $\mathrm{P}<0.001$ & $\mathrm{P}<0.01$ & $\mathrm{P}<0.05$ \\
\hline
\end{tabular}

Notes: AKI and CKI - acute and chronic kidney injury; AAP i ASDH - activity of alkaline phosphatase and succinate dehydrogenase; $\mathrm{P}$ - significance of differences compared to control; $\mathrm{P}_{1}$ - significance of differences compared to untreated rats.

gen utilization in renal tissues with high level of aerobic energy exchange due to 2,4-dinitrophenol effect. Energy deficit in the nephrocytes first of all led to the violation of the functional state of proximal tubules and standardized by GF proteinuria increased by 1.5 times. Despite the versatility of regulatory and compensatory mechanisms of adaptation to hypoxia in the more distant period of HHHN there was an increase of protein concentration in the urine by $44.4 \%$, increase of protein excretion in two hours and protein excretion calculated for $100 \mu 1$ of GF by $27.3 \%$ and $94.4 \%$, respectively.

The use of $\mathrm{K}_{\mathrm{ATP}}$-channels activator during 7 days hampers kidney injury by the causative agents of hemic and cytotoxic hypoxia. The protective effect of flocalin on the proximal part of the nephron manifested as a decrease of protein concentration in the urine of rats with acute HHHN of 1.8 times and a decrease of the standardized by GF proteinuria of 1.6 and 2.1 times in acute and chronic injury of the nephrocytes, respectively.

The antiproteinuric effect that we obtained gave evidence of the protective influence of $\mathrm{K}_{\mathrm{ATP}^{-}}$ channels opening predominantly in the tubular part of nephron. The reduction of the nephrocytes overloading with protein, first of all with albumin occurred due to flocalin induced improvement of reabsorption. The sign of positive changes in the tubulocytes in the rats with correction of nephropathy was the elevation of AP activity which is a marker of the state of the brush border of proximal tubules in renal cortex (Table 2).

The diminution of protein reabsorption and tubular proteinuria in sublimate injury were followed by the decrease of AP in renal cortex by $57.5 \%$ in acute period and by $36.5 \%$ in the chronic stage of toxic pathology. In the rats with acute HHHN AP activity decreased by $20.4 \%$ 
and in chronic process it decreased by $5.4 \%$. According to the selected periods of assessment after the use of flocalin AP activity increased by 54.1 and $49.4 \%$ in the rats with sublimate nephropathy and by 18.1 and $4 \%$ in the rats with hypoxic kidney injury.

Similar changes were found regarding SDH activity in renal cortex which plays a very important role in the system of energy metabolism. $\mathrm{SDH}$ in the rats with acute and chronic damage of the nephrocytes decreased by 30.8 and $41.2 \%$ and in the rats with acute and chronic HHHN it decreased by 40 and $75.6 \%$, respectively. Activation of $\mathrm{K}_{\mathrm{ATP}}$-channels increased this index by 36.3 and $56.7 \%$ in acute and chronic sublimate nephropathy. In the rats with acute HHHN activity of SDH reached control level and it increased by $71.2 \%$ in the group with chronic HHHN.

Thereby antiproteinuric effect after $\mathrm{K}_{\text {ATP }}{ }^{-}$ channels activation is associated primarily with improvement of the functional state of the proximal part of the nephron where in convoluted tubule protein reabsorption takes place. Our previous results of ion regulating kidney function assessment [15] have shown that flocalin administration activates voltage-dependent proximal transport of sodium ions. The use of flocalin in the mentioned experimental conditions increased the activity of SDH, a marker of the functional state of mitochondria and of AP, a phosphor donator for ATP in renal cortex with $\mathrm{S}_{1}$ and $\mathrm{S}_{2}$ segments of the proximal tubules. The intensified outflow of potassium ions and reduced inflow of calcium ions to the smooth muscle cells led to the dilation of vessels, improvement of renal blood flow, decrease of the negative influence of nephrotoxins on energy metabolism of tubulocytes that are highly sensitive to hypoxia. The decreased activity of SDH in renal medulla reached the control level only in the rats with chronic sublimate nephropathy after the use of flocalin. The segments of the nephron are characterized by a number of functional and biochemical differences that determine the types of ion channels and their subunits. There is no clear idea of the types of ion channels in the kidneys today however $\mathrm{K}_{\mathrm{ATP}}$-channels in the proximal part of the nephron are identified. The use of flocalin showed positive dynamics of AP and SDH enzyme activity predominantly in the cortical layer. The majority of the proximal tubules are localized in renal cortex. The improvement of reabsorption in this part of the nephron is a weighty component of the protective effect of pharmacological agents. It is proven by the received antiproteinuric effect. It should be noted that evaluation of the influence of flocalin on cardiovascular system and the studies of cardioprotection mechanisms had been performed only in acute experiments previously [16]. Our experimental analysis has shown that the nephroprotective influence of flocalin induced $\mathrm{K}_{\text {ATP }}$-channels activation appears after induction of both acute and chronic pathological processes. The functional adaptation of the damaged kidney in such conditions is characterized by the common and specific for every stage mechanisms that determines different directions of pathogenetic therapy.

Thus, flocalin induced $\mathrm{K}_{\mathrm{ATP}}$-channels activation has led to the decrease of proteinuria in the rats with acute and chronic kidney damage caused by the nephrotoxic effect of sublimate and combined histohemic hypoxia. The elevation of protein excretion standardized by GF has pointed at the predominant tubular origin of proteinuria due to primary damage of the proximal part of nephron regardless of the etiology of nephropathy. The use of flocalin was followed by the increase of AP and SDH activity in renal cortex of rats in acute period of sublimate nephropathy and HHHN, as well as in chronization of these pathological processes. Combination of the antiproteinuric effect and the improvement of energy supply of the functional state of the nephrocytes in renal cortex points at the nephroprotective effect of $\mathrm{K}_{\mathrm{ATP}}$-channels activation with flocalin predominantly in the proximal part of the nephron.

The authors of this study confirm that the research and publication of the results were not associated 
with any conflicts regarding commercial or financial relations, relations with organizations and/or individuals who may have been related to the study, and interrelations of coauthors of the article.

\section{Н.Д. Філіпець ${ }^{1}$, А.І. Гоженко ${ }^{2}$, О.О. Філіпець ${ }^{1}$, О.А. Гоженко ${ }^{2}$, В.М. Сірман ${ }^{2}$}

\section{АНТИПРОТЕЇНУРИЧНИЙ ЕФЕКТ АК- ТИВАТОРА АТФ-ЧУТЛИВИХ КАЛІЕВИХ КАНАЛІВ ФЛОКАЛІНУ НА МОДЕЛЯХ ЕКСПЕРИМЕНТАЛЬНИХ НЕФРОПАТІЙ}

В експериментах на лабораторних нелінійних білих щурах із сулемовою нефропатією (дихлорид ртуті, 5 мг/кг підшкірно) та гіпоксичною гістогемічною нефропатією (ГГГН; нітрит натрію, 50 мг/кг підшкірно і 2,4-динітрофенол, 3 мг/кг внутрішньочеревинно) досліджено вплив активації АТФ-чутливих калієвих $\left(\mathrm{K}_{\text {АТФ}}\right)$ каналів флокаліном (5 мг/кг внутрішньошлунково, 7 діб) на екскрецію протеїну нирками. Після введення флокаліну зменшується стандартизована за клубочковою фільтрацією протеїнурія: у 4,5 і 1,2 рази у щурів із гострою та хронічною сулемовою нефропатією; за умов гіпоксичного пошкодження нефроцитів - відповідно в 1,6 та 2,1 рази. Антипротеїнуричний ефект флокаліну в гострому і хронічному періоді нефропатій супроводжується збільшенням у кірковому шарі нирок активності ензимів лужної фосфатази (на 54,1 і 49,9 \% - у щурів із сулемовою нефропатією; на 18,1 і 4 \% - у щурів із ГГГН) та сукцинатдегідрогенази (на 36,3 і 56,7 \% - за умов гострої та хронічної сулемової нефропатії; досягає контролю у щурів із гострою ГГГН і на 71,2 \% підвищується у щурів із хронічною ГГГН. Зроблено висновок про нефропротекторний вплив активації $\mathrm{K}_{\text {АТФ}}$-каналів флокаліном переважно в проксимальному відділі нефрону.

Ключові слова: активатор АТФ-чутливих калієвих каналів флокалін; експериментальна нефропатія.

${ }^{1}$ Вищий державний навчальний заклад Украӥни «Буковинський державний медичний університет», Чернівиі; ${ }^{2}$ Держскне підприємство «Український науково-дослідний інститут медииини транспорту МОЗ Украӥни», Odeca; e-mail: filipec.natalja@bsmu.edu.ua

\section{Н.Д. Филипец ${ }^{1}$, А.И. Гоженко ${ }^{2}$, Е.А. Филипец ${ }^{1}$, Е.А. Гоженко ${ }^{2}$ В.М. Сирман ${ }^{2}$ \\ АНТИПРОТЕИНУРИЧЕСКИЙ ЭФФЕКТ АКТИВАТОРА АТФ-ЧУВСТВИТЕЛЬНЫХ КАЛИЕВЫХ КАНАЛОВ ФЛОКАЛИНА НА МОДЕЛЯХ ЭКСПЕРИМЕНТАЛЬНЫХ НЕ- ФРОПАТИЙ}

В экспериментах на лабораторных нелинейных белых крысах с сулемовой нефропатией (дихлорид ртути 5 мг/ кг подкожно) и гипоксической гистогемической нефропатией (ГГГН; нитрит натрия, 50 мг/кг подкожно и 2,4-динитрофенол, 3 мг/кг внутрибрюшинно) исследовано влияние активации АТФ-чувствительных калиевых $\left(\mathrm{K}_{\text {АТФ}}\right)$ каналов флокалином (5 мг/кг внутрижелудочно, 7 дней) на экскрецию протеина почками. После введения флокалина уменьшается стандартизованная по клубочковой фильтрации протеинурия: в 4,5 и 1,2 раза у крыс с острой и хронической сулемовой нефропатией; в условиях гипоксическогого повреждения нефроцитов - соответственно в 1,6 и 2,1 раза. Антипротеинурический эффект флокалина в остром и хроническом периоде нефропатий сопровождается увеличением в корковом веществе почек активности энзимов щелочной фосфатазы (на 54,1 и 49,9 \% - у крыс с сулемовой нефропатией; на 18,1 и $4 \%$ - у крыс с ГГГН) и сукцинатдегидрогеназы (на 36,3 и 56,7 \% - в условиях острой и хронической сулемовой нефропатии; достигает контроля у крыс с острой ГГГН и на 71,2 \% повышается у крыс с хронической ГГГН. Сделан вывод о нефропротекторном влиянии активации $\mathrm{K}_{\text {АТФ}}$-каналов флокалином преимущественно в проксимальном отделе нефрона.

Ключевые слова: активатор АТФ-чувствительных калиевых каналов флокалин; экспериментальная нефропатия.

\section{REFERENCES}

1. Noma A. ATP-regulated $\mathrm{K}^{+}$channels in cardiac muscle. Nature. 1983;305(5930):147-48.

2. Sikka P, Kapoor S, Bindra VK, Saini M, Saxena KK. Iptakalim: A novel multi-utility potassium channel opener. J Pharmacol Pharmacother. 2012;3(1):12-4.

3. Afzal MZ, Reiter M, Gastonguay C, McGivern JV, Guan X, Ge ZD, Mack DL, Childers MK, Ebert AD, Strande JL. Nicorandil, a nitric oxide donor and ATP-sensitive potassium channel opener, protects against dystrophindeficient cardiomyopathy. J Cardiovasc Pharmacol Ther. 2016;21(6):549-62.

4. Zhang X, Zhang X, Xiong Y, Xu C, Liu X, Lin J, Mu G, Xu S, Liu W. Sarcolemmal ATP-sensitive potassium channel protects cardiac myocytes against lipopolysaccharideinduced apoptosis. Int J Mol Med. 2016;38(3):758-66.

5. Pyvovar SN, Korzhov VI, Strutinskii RB, Yagupolskii LM, Moibenko AA. The influence of the fluor-containing mitochondrial K ATP channels openers on the oxidative phosphorilation. Fiziol Zh. 2006;52(3):25-3. [Ukrainian].

6. Strutynskyi RB, Moybenko OO, Chebanov VA, Gorobets NYu. Modeling of production industrial process of the drug flocalin and search of its optimally effective dose for treatment of heart diseases. Sci Innov. 2013;9(1):55-3. [Ukrainian].

7. Gozhenko AI. Functional-and-metabolic continuum. J NAMS of Ukraine. 2016;22(1):3-8. [Ukrainian].

8. Castrop H, Höcherl K, Kurtz A, Schweda F, Todorov V, Wagner C. Physiology of kidney renin. Physiol Rev. 2010;90:607-74.

9. Humphries ESA, Dart C. Neuronal and cardiovascular potassium channels as therapeutic drug targets. J Biomol 
Screen. 2015;20(9):1055-73.

10. Moybenko OO, Strutynskyi RB, Yagupolskii LM, Mohort MA. Creation and preparation of the new domestic cardioprotective drug - fluorine containing activator of ATP dependent potassium channel flokalin to put into operation. Sci Innov. 2006;2(4):77-2. [Ukrainian].

11. Gozhenko AI, Kravchuk AV, Nikitenko OP, Moskolenko OM, Sirman VM. Renal functional reserve. Odessa: Fenix; 2015. [Ukrainian].

12. Pak LB, Dubikov AI, Kabanceva TA, Vasilyuk AA, Grigoryan OM. Apoptosis and nephropathies. Nephrology. 2013;17(4): 36-3. [Russian].

13. Gozhenko AI, Filipets ND. The functional state of kidneys after adenosine triphosphate sensitive potassium channels activation in experimental acute hypoxia. Fiziol $\mathrm{Zh}$.
2014;60(4):22-9. [Ukrainian].

14. Mahalyas VM, Myhyeyev AO, Rohovyy YuYe. Modern methods experimental and clinical studies of the central research laboratory BSMA. Chernivtsi: BSMA; 2001. [Ukrainian].

15. Filipets ND, Gozhenko AI. Comparative assessment of nephroprotective properties of potassium and calcium channel modulators in experimental renal injury. Eksp Klin Farmakol. 2014;77(1):10-2. [Russian].

16. Strutynskyi RB, Kotsuruba AV, Rovenets RA, Strutynska NA, Yagupolskii YL, Sagach VF, Moibenko OO. Biochemical mechanisms of cardioprotective action of the drug product Flocalin, ATP-sensitive $\mathrm{K}^{+}$channel opener, in myocardial ischemia-reperfusion. Int J Phys Pathophys. 2014;5(3):231-44. [Ukrainian].

Received 03.07.2017 